\title{
MINNESOTA LEISURE TIME PHYSICAL ACTIVITY QUESTIONNAIRE AS AN ADDITIONAL TOOL IN CLINICAL ASSESSMENT OF PATIENTS WITH CORONARY ARTERY DISEASE TREATED WITH ANGIOPLASTY
}

\author{
Zbigniew Nowak, Agata Nowak
}

Out of many methods used for assessment of physical activity, a questionnaire seems to be a simple and affordable method of assessing the risk of occurrence of coronary insufficiency. However the number of clinical studies done on the application of physical activity questionnaires is limited.

Aim. The objective of the present study was to analyze the suitability of Minnesota Leisure Time Physical Activity Questionnaire (MLTPAQ) in assessment of physical activity in patients after percutaneous coronary intervention (PCI)

Material and methods. Design: prospective analysis - before and 6 months after $\mathrm{PCl}$ and correlation between level of physical activity and physical capacity assessed with treadmill exercise test (ET), ejection fraction (LVEF\%) Setting: Upper Silesia Medical Center. Department of cardiology. Population: One hundred fiftieth four inpatients (mean of $56 \mathrm{y}$ ), among which there were patients with acute myocardial infarction (MI), with history of past $\mathrm{MI}$ and with IHD without MI. All subjects underwent coronarography procedure with optional $\mathrm{PCl}$. All patients underwent phase I and II cardiac rehabilitation. The MLTPAQ was administered to all patients at the time of $\mathrm{PCl}$ and then 6 months later, so was the treadmill stress test (TST) and echocardiography (ECHO).

Results. Total energy expenditure calculated with the MLTPAQ remained at the same level and was of low intensity ( $<4 \mathrm{MET},<2000 \mathrm{kcal} /$ week) 6 months after the $\mathrm{PCl}$. There was an increased physical capacity noted 6 months after initial $\mathrm{PCl}$ : increased metabolic cost (MET); maximal oxygen consumption $\left(\mathrm{VO}_{2 \max }\right)$; maximal heart rate $\left(\mathrm{HR}_{\max }\right)$ obtained during the TST and decreased resting heart rate $\left(\mathrm{HR}_{\text {rest }}\right)$. ECHO examination showed improved LVEF\%.

Clinical Rehabilitation Impact: the helpfulness of the research may be used in the work of cardiologists or physiotherapists. The research will allow to estimate the actual level of physical activity and physical endurance of patients that were treated by angioplasty. Moreover, this is the simple and cheap method of estimation.
Conclusion. Despite increased physical capacity and improved heart hemodynamic resulting most likely from $\mathrm{PCl}$ procedure, patients presented with similar level of leisure time physical activity 6 months after the PCl.

Russ J Cardiol 2014, 4 (108), Engl.: 54-59

Key words: ischemic heart disease, percutaneous coronary intervention, physical activity questionnaire, treadmill stress test, echocardiography.

Academy of Physical Education, Faculty of Physiotherapy Katowice, Poland

Corresponding author. Zbigniew Nowak Prof, PhD, Academy of Physical Education, Faculty of Physiotherapy, Mikolowska Str.72B, 40-065 Katowice, Poland, Tel: +48322075301, Fax: +48322511097, e-mail zbinow@gmail.com

CAD - coronary artery disease, ET - exercise test, HA - household activity, IHD - ischemic heart disease, LVEF\% - left ventricular ejection fraction, LVESD - left ventricular end-systolic diameter, MET - increased metabolic cost, MI - myocardial infarction, MLTPAQ - Minnesota Leisure Time Physical Activity Questionnaire, $\mathrm{PCl}$ - percutaneous coronary intervention, RA - recreational activity, TST — treadmill stress test.

Received September 04, 2013.

Revision received September 24, 2013.

Accepted October 01, 2013.

\section{МИННЕСОТСКИЙ ОПРОСНИК ФИЗИЧЕСКОЙ АКТИВНОСТИ В КАЧЕСТВЕ ДОПОЛНИТЕЛЬНОГО ИНСТРУМЕНТА ДЛЯ КЛИНИЧЕСКОЙ ОЦЕНКИ ПАЦИЕНТОВ С ИШЕМИЧЕСКОЙ БОЛЕЗНЬЮ СЕРДЦА ПОСЛЕ АНГИОПЛАСТИКИ}

\section{Zbigniew Nowak, Agata Nowak}

Из многих методов, используемых для оценки физической активности, анкеть кажутся простым и недорогим методом оценки риска возникновения коронарной недостаточности. Однако количество клинических исследований, проведенных на применении анкетирования физической активности анкет, ограничено.

Цель. Целью настоящего исследования был анализ пригодности Миннесотского опросника физической активности (MLTPAQ) в оценке физической активности пациентов после чрескожного коронарного вмешательства (ЧКВ) Материал и методы. Дизайн: перспективное исследование - до и через 6 месяцев после ЧКВ и корреляция между уровнем физической активности и физической способности, оцениваемой с помощью тредмил-теста с физической нагрузкой (ТТ), фракции выброса (ФВ ЛЖ\%). Выполнено: в Медицинском центре Верхней Силезии, отделение кардиологии. Пациенты: 154 пациента в стационаре (средний возраст 56 лет), среди которых были пациенты с острым инфарктом миокарда (ИМ), ИМ в анамнезе и с ИБС без ИМ. Bсе пациенты были подвергнуты коронарографии с возможным ЧКВ. Все пациенты прошли этапы I и |I сердечной реабилитации.

Опросник предлагался всем пациентам во время проведения ЧКВ и затем через 6 месяцев, как и тредмил-тест (TST) и эхокардиография (ЭХО).

Результаты. Общий расход энергии, рассчитанный с помощью MLTPAQ, остался на прежнем уровне и был низкой интенсивности (<4 MET, <2000 kcal/ неделю) в 6 месяцев после ЧКВ. Отмечено увеличение физической работоспособности через 6 месяцев после первоначального ЧКВ: увеличение энергетических затрат (MET); максимального потребления кислорода $\left(\mathrm{VO}_{2}\right)$; максимальный сердечный ритм ( $\left.\mathrm{HR}_{\max }\right)$ был получен в ходе TST, снизилась частота пульса в спокойном состоянии (HRrest). ЭХО исследование показало улучшение ФВ ЛЖ,\%.

Клиническое воздействие реабилитации: полезность исследования может быть использована в работе врачей-кардиологов или физиотерапевтов. Исследование позволит определить реальный уровень физической активности и физической выносливости пациентов, которые лечились с помощью ангиопластики. Кроме того, это самый простой и дешевый метод оценки.

Заключение. Несмотря на увеличение физической способности и улучшение сердечной гемодинамики в результате ЧКВ, пациенты показали одинаковый уровень физической активности через 6 месяцев после ЧКВ

Российский кардиологический журнал 2014, 4 (108), Англ.: 54-59

Ключевые слова: ишемическая болезнь сердца, чрескожное коронарное вмешательство, анкеты физической активности, тредмил-тест, эхокардиография. 


\section{Introduction}

In recent years there have been many papers published on the research methods aimed at measurement of physical activity. Some were based on monitoring of selected physiological parameters such as heart rate and whole body movements with the use of accelerometers or pedometers [1-3]. Other were aimed at assessment of energy expenditure derived from food, using direct and indirect calorimetry, kinematic analysis as well as doubly labelled water [4]. In epidemiological studies, the application of such methods is limited due to high costs, potential contraindications, advanced age of subjects, their health status and low reliability. It seems that a questionnaire constitutes a simple and inexpensive tool in assessment of physical activity [6-9]. In some questionnaires only occupational activity is of interest, in others, only leisure time exercise, but many seek information about activity both on and off the job.

The questionnaires assess the physical activity over a wide age range for various periods of time - the previous $24 \mathrm{hr}$, the previous week, month or even a year [7,9].

The data obtained in this way allows for calculation of average energy expenditure of an individual, which informs us whether the form, frequency and intensity of physical activity reach the values required for prevention and treatment of many so-called civilization diseases.

Such measurement is of great importance, since the sedentary lifestyle is one of the risk factor responsible for occurrence of IHD and at the same time physical activity constitutes a major factor in treatment and secondary prevention of IHD [10, 11].

However, the number of studies done on the application of questionnaires for clinic purposes in patients with IHD is limited. We attempted to answer the following questions:

1. What is the average weekly amount of physical activity and energy expenditure calculated using the MLTPAQ in patients with coronary artery disease (CAD) before and after percutaneous coronary intervention (PCI)?

2. Do obtained questionnaire results correlate with the level of physical capacity [assessed with submaximal treadmill exercise test (ET)] and cardiac haemodynamical parameterEjection Fraction (evaluated with echocardiography), making it a usable tool in clinical studies?

3. Is there a correlation between the obtained questionnaire results and combined endpoint?

\section{Material and methods}

The study group consisted of 211 patients, aged between $32-74$ years (mean age of $56 \pm 7$ ), among which there were patients with acute MI, with history of past MI and with IHD without MI. Patients with post-MI complications such as cardiogenic shock, circulatory arrest, pericarditis, resting arrhythmias and heart conductivity disorders were excluded from the study. All patients were informed about the type and aim of the research and they gave written informed consent before participating in the study. Subjects were told that they may withdraw from the study at any time. The study was approved by the Senate Ethics Committee of the Academy of Physical Education in Katowice, Poland.

All subjects underwent coronarography procedure with optional percutaneous coronary intervention (PCI). Out of 154 patients $32(20,77 \%)$ did not receive stent implantation, 108 subjects $(70.12 \%)$ received one stent, while $8(5,19 \%)$ two stents implantation. All patients underwent phase I, inpatient cardiac rehabilitation which lasted from 5 to 7 days. After hospitalization all patients were referred to phase II, 24-day cardiac rehabilitation in health resort (sanatorium). All subjects filled the MLTPAQ twice: first, at the time of hospitalization due to PCI procedure, and then for the second time after the lapse of 6 months. The MLTPAQ results enabled the calculation of the level of recreational physical activity and household activities during leisure time. The results were expressed in a weekly value [ $\mathrm{kcal} /$ week] after dividing the calculated 6-month energy expenditure by 26 weeks. The following ranges of activity intensity were used: low $[<4$ MET], medium [ $4-<6$ MET] and high $[\geq 6$ MET], where 1 MET equals the resting metabolic rate, which is approximately $3.5 \mathrm{ml}$ oxygen $\mathrm{kg}^{-1}$ body weight per $\mathrm{min}^{-1}$. The value of total averaged weekly energy expenditure was calculated separately for recreational activity (RA) and household activity (HA) (shopping, cleaning, gardening, house remodelling and repairing). Additional categorization of weekly energy expenditure into 4 ranges was also made: $\leq$ 999, 1000-1999, 2000-2999, $\geq 3000$ [kcal/week]. The MET for a given activity value was calculated according the Compendium of Physical Activities Tracking Guide [12]. In order to increase reliability of the questionnaire calculations (avoiding possible misunderstanding of some questions, especially those concerning the time of activity) the authors of this study read the questions of the MLTPAQ and filled in the questionnairesforpatientsduring individualappointments.

The level of work capacity was assessed with the use of submaximal treadmill stress test (according to Bruce's protocol) performed 1-3 months before the initial PCI procedure and 6 months after. The following variables of stress test were subjected to statistical analysis: test duration [min], metabolic cost [MET], resting and the highest recorded value of heart rate [beats/min], maximal oxygen consumption $\mathrm{VO}_{2} \max [\mathrm{ml}]$ and the reason for stress test termination: submaximal value of HRmax (85\%) calculated with formula: HR $\max =208-07 \mathrm{x}$ age, fatigue, stenocardia, changes of S-T segment in electrocardiogram (ECG), occurrence of arrhythmias, heart conductivity disorders and excessive increase in arterial blood pressure. The value of $\mathrm{VO}_{2}$ max was calculated according to the following formula [13]:

$\mathrm{VO}_{2} \max =13,3-0,03(\mathrm{t})+0,297\left(\mathrm{t}^{2}\right)-0,0077\left(\mathrm{t}^{2}\right)+$ 4,2 (CHS),

where, $\mathrm{t}$ - time [minutes], CHS - cardiac health status, 1- patients with angina pectoris, after MI, after 
Results of treadmill stress test at the time of $\mathrm{PCl}$ and 6 months after

\begin{tabular}{|c|c|c|c|}
\hline Parametr & at the time of $\mathrm{PCl}, \mathrm{N}=154$ & 6 months after $\mathrm{PCl}, \mathrm{N}=150$ & $P$ \\
\hline Stress test time [min] & $4,24 \pm 2,22$ & $6,32 \pm 3,12$ & $<0,001$ \\
\hline MET & $6,52 \pm 1,26$ & $8,21 \pm 2,86$ & $<0,001$ \\
\hline $\mathrm{VO}_{2} \max [\mathrm{ml}]$ & $28,23 \pm 5,94$ & $32,52 \pm 8,25$ & $<0,001$ \\
\hline Resting HR [beats/min] & $72 \pm 4,23$ & $70 \pm 6,22$ & $<0,001$ \\
\hline $\mathrm{HR}_{\max }$ at the test [beats/min] & $118 \pm 14,52$ & $129 \pm 16,47$ & $<0,001$ \\
\hline
\end{tabular}

Abbreviations: $\mathrm{PCl}$ - percutaneous coronary intervention, $\mathrm{MET}$ - metabolic cost, $\mathrm{VO}_{2}$ max - maximal oxygen consumption, $\mathrm{HR}_{\text {rest }}$ - resting heart rate, $\mathrm{HR}_{\text {max }}-$ maximal heart rate.

Table 2 For variables with non-normal distribution, U Mann-

Indications for treadmill stress test termination

\begin{tabular}{|l|l|l|l|l|}
\hline $\begin{array}{l}\text { Indications for stress test } \\
\text { termination }\end{array}$ & \multicolumn{3}{|l|}{ at the time of $\mathrm{PCl}$} & \multicolumn{3}{l|}{6 months after $\mathrm{PCl}$} \\
\hline Reaching submaximal HR & $\mathrm{N}$ & $\%$ & $\mathrm{~N}$ & $\%$ \\
\hline Other† & 19 & 12,33 & 118 & 78,66 \\
\hline Total & 135 & 87,67 & 32 & 21,34 \\
\hline & 154 & 100 & 150 & 100 \\
\hline
\end{tabular}

Abbreviations: $\mathrm{PCl}-$ percutaneous coronary intervention, $\mathrm{HR}$ - heart rate. ${ }^{\dagger}$ stenocardia, S-T segment changes in ECG, occurrence of arrhythmias and heart conductivity disorders, excessive increase in arterial blood pressure.

\section{Echocardiography results}

\begin{tabular}{|l|l|l|l|}
\hline Parametr & at the time of $\mathrm{PCl}, \mathrm{N}=154$ & 6 months after $\mathrm{PCl}, \mathrm{N}=150$ & $\mathrm{P}$ \\
\hline LVEF\% & $50,45 \pm 7,21$ & $51,36 \pm 6,12$ & $<0,02$ \\
\hline
\end{tabular}

Abbreviations: $\mathrm{PCl}$ - percutaneous coronary intervention, LVEF\% - left ventricular ejection fraction.

PCI, 0 - patients without clinical symptoms of angina pectoris, without history of MI or PCI.

Left ventricular ejection fraction (LVEF\%) was analyzed. The assessment of heart structure was done with 2-dimennsional echocardiography (HP Sonos 1100) by a physician, cardiology specialist, after completion of echocardiography training.

All statistical analyses were performed using Statistica (v. 7.1) software, Statsoft USA and MedCalc software (v.8.0.0.1) by F. Schoonjans and included the calculation of means and standard deviations (SD) of variables. The distribution of means was evaluated with Wilk-Shapiro test for normality. A criterion of $p<.05$ defined statistical significance. Student's t-test for independent variables with normal distribution was used. This test was preceded by the Fisher's test for verification of the homogeneity of variance. In case the variance was not equal, Sattherwaite's test was used. Student's t-test for dependent variables was also used, as well as one-way variance analysis proceeded by Bartlett's test for verification of variance homogeneity.
Whitney test, Kruskall-Wallis ANOVA test and Sperman's rang correlation test were used.

\section{Results}

Out of 211 patients who initially underwent PCI procedure, there were 207 subjected to the second questionnaire administration (2 patients died due to coronary insufficiency in second and fifth month after the PCI, 2 patients resigned from the study due to general discomfort). Compared to the stress test performed at the time of the initial PCI procedure, the improvement of patients' physical capacity was noted during the treadmill stress test: increased metabolic cost (MET); maximal oxygen consumption $\left(\mathrm{VO}_{2 \max }\right)$; maximal heart rate $\left(\mathrm{HR}_{\max }\right)$ obtained during the test and decreased resting heart rate $\left(\mathrm{HR}_{\text {rest }}\right)$ (Table 1$)$. The number of patients who terminated the stress test due to pathological reasons reduced (Table 2 ).

After the 6-month period, there was a favourable tendency noted in the changes of heart hemodynamic, though only in the case of EF\% statistical significance was observed (Table 3 ).

The total energy expenditure from the leisure time activities calculated with the MLTPAQ was higher 6 months after the angioplasty procedure (2829,52 vs $2799,92 \mathrm{kcal} /$ week). As far as physical activity of low intensity was concerned, there was an increase noted $(1759,30 \mathrm{vs} 1811,06 \mathrm{kcal} /$ week). The values of activity of medium and high intensity dropped from 1300,99 to 1190,46 and from 714,63 to $491,73 \mathrm{kcal} /$ week, respectively. Nevertheless, none of the above changes were statistically significant. The value of recreational activity was higher 6 months after the angioplasty for the range of low intensity $(<4 \mathrm{MET})$ and in majority of patients did not exceed $3000 \mathrm{kcal} /$ week. For the range of medium intensity (4-6 MET) it stayed under 2000 $\mathrm{kcal} /$ week in majority of patients. In the range of high intensity $(>6 \mathrm{MET})$ it did not exceed $1000 \mathrm{kcal} /$ week in those few patients who presented with that level of intensity. In case of household activity, there was an increase noted in medium range of intensity (4-6MET) which did not exceed $3000 \mathrm{kcal} /$ week in majority of patients. For the household activities of high intensity 


\section{Types and ranges of physical activity energy expenditure calculated with the MLTPAQ}

Table 4

\begin{tabular}{|c|c|c|c|c|c|c|c|c|c|c|c|c|}
\hline \multicolumn{2}{|l|}{ Parameter } & \multicolumn{2}{|c|}{ below $999 \mathrm{kcal}$} & \multicolumn{2}{|c|}{$1000-1999 \mathrm{kcal}$} & \multicolumn{2}{|c|}{$2000-2999 \mathrm{kcal}$} & \multicolumn{2}{|c|}{ over $3000 \mathrm{kcal}$} & \multicolumn{3}{|l|}{ TOTAL } \\
\hline & & $\begin{array}{l}\text { before } \\
\mathrm{PCl}\end{array}$ & $\begin{array}{l}6 \text { months } \\
\text { after } \mathrm{PCl}\end{array}$ & before $\mathrm{PCl}$ & $\begin{array}{l}6 \text { months } \\
\text { after } \mathrm{PCl}\end{array}$ & $\begin{array}{l}\text { before } \\
\mathrm{PCl}\end{array}$ & $\begin{array}{l}6 \text { months after } \\
\mathrm{PCl}\end{array}$ & $\begin{array}{l}\text { before } \\
\mathrm{PCl}\end{array}$ & $\begin{array}{l}6 \text { months } \\
\text { after } \mathrm{PCl}\end{array}$ & $\begin{array}{l}\text { before } \\
\mathrm{PCl}\end{array}$ & $\begin{array}{l}6 \text { months } \\
\text { after PCl. }\end{array}$ & $P$ \\
\hline & & \multicolumn{8}{|c|}{ Low intensity < 4 MET } & & & \\
\hline \multirow[t]{3}{*}{ RA } & Mean & 498,18 & 521,75 & 1333,52 & 1451,66 & 2445,65 & 2512,62 & 4186,59 & 4105,97 & 1619,94 & 1707,99 & $<0,24$ \\
\hline & SD & 270,17 & 212,64 & 216,62 & 220,38 & 329,21 & 312,40 & 875,31 & 601,03 & 1232,93 & 1104,06 & \\
\hline & $\mathrm{N}$ & 51 & 52 & 54 & 65 & 20 & 20 & 7 & 6 & 132 & 143 & \\
\hline \multirow[t]{3}{*}{ HA } & Mean & 191,46 & 429,11 & 1210,46 & - & 2312,30 & 2403,93 & 4116,90 & 4000,07 & 1632,29 & 1320,53 & $<0,34$ \\
\hline & SD & 45,54 & 201,79 & 33,97 & - & - & 152,60 & 427,10 & 187,11 & 1611,22 & 1481,89 & \\
\hline & $\mathrm{N}$ & 5 & 10 & 3 & 0 & 1 & 2 & 4 & 4 & 13 & 16 & \\
\hline \multirow[t]{4}{*}{ Total } & Mean & 435,65 & 501,51 & 1235,39 & 1366,11 & 2568,12 & 2489,92 & 4452,98 & 4481,01 & 1729,10 & 1801,14 & $<0,31$ \\
\hline & SD & 292,09 & 232,50 & 233,37 & 222,51 & 307,08 & 309,43 & 1076,02 & 900,03 & 1421,13 & 1291,56 & \\
\hline & $\mathrm{N}$ & 56 & 51 & 23 & 35 & 40 & 7 & 19 & 3 & 131 & 138 & \\
\hline & & \multicolumn{8}{|c|}{ Medium intensity $4->6$ MET } & & & \\
\hline \multirow[t]{3}{*}{ RA } & Mean & 309,90 & 420,33 & 1318,01 & 1501,26 & 2500,76 & 2401,10 & 3048,04 & 4623,12 & 545,12 & 601,18 & $<0,11$ \\
\hline & SD & 253,55 & 261,49 & 324,92 & 223,30 & 190,19 & 288,27 & - & - & 534,81 & 641,21 & \\
\hline & $\mathrm{N}$ & 84 & 85 & 22 & 10 & 9 & 4 & 4 & 2 & 119 & 101 & \\
\hline \multirow[t]{3}{*}{ HA } & Mean & 371,91 & 524,22 & 1418,24 & 1495,28 & 2417,56 & 2484,60 & 4410,14 & 3765,73 & 1064,42 & 1011,12 & $<0,45$ \\
\hline & SD & 245,38 & 290,29 & 278,60 & 302,84 & 99,96 & 412,87 & 1295,59 & 531,09 & 1529,76 & 1129,48 & \\
\hline & $\mathrm{N}$ & 65 & 66 & 21 & 28 & 5 & 5 & 13 & 11 & 104 & 110 & \\
\hline \multirow[t]{3}{*}{ Total } & Mean & 415,37 & 515,90 & 1541,89 & 1352,59 & 2320,16 & 2355,92 & 4221,67 & 4112,71 & 1289,85 & 1088,42 & $<0,71$ \\
\hline & SD & 111,00 & 207,23 & 292,12 & 296,89 & 125,83 & 283,95 & 1007,42 & 568,86 & 1326,26 & 1198,55 & \\
\hline & N & 74 & 81 & 34 & 29 & 12 & 15 & 12 & 8 & 132 & 133 & \\
\hline \multicolumn{13}{|c|}{ High intensity $>6$ MET } \\
\hline \multirow[t]{3}{*}{ RA } & Mean & 372,70 & 321,41 & 1226,15 & 1561,54 & - & 2225,00 & 3113,01 & 5226,14 & 511,94 & 643,90 & $<0,6$ \\
\hline & SD & 224,21 & 232,07 & 22,12 & - & - & - & - & - & 621,73 & 1005,01 & \\
\hline & $\mathrm{N}$ & 24 & 21 & 3 & 1 & 0 & 1 & 1 & 1 & 28 & 24 & \\
\hline \multirow[t]{3}{*}{ HA } & Mean & 332,15 & 231,94 & 1409,01 & 1206,15 & 2015,38 & - & 4644,61 & - & 723,74 & 195,34 & $<0,6$ \\
\hline & SD & 180,21 & 181,79 & - & - & - & - & - & - & 1220,53 & 252,87 & \\
\hline & $\mathrm{N}$ & 18 & 25 & 2 & 2 & 1 & 0 & 5 & 0 & 26 & 28 & \\
\hline \multirow[t]{3}{*}{ Total } & Mean & 361,61 & 281,26 & 1354,15 & 1396,15 & 2195,38 & 2068,45 & 4126,15 & 5106,14 & 700,63 & 391,73 & $<0,9$ \\
\hline & SD & 272,61 & 219,48 & 307,81 & 230,48 & - & - & 1293,36 & - & 1092,74 & 806,73 & \\
\hline & $\mathrm{N}$ & 34 & 39 & 6 & 3 & 2 & 1 & 3 & 1 & 45 & 44 & \\
\hline \multirow{3}{*}{$\begin{array}{l}\text { Total energy } \\
\text { expenditure }\end{array}$} & Mean & 581,11 & 589,29 & 1449,74 & 1530,92 & 2477,41 & 2499,81 & 4796,96 & 4536,78 & 2363,11 & 2412,53 & $<0,6$ \\
\hline & SD & 292,31 & 199,13 & 154,43 & 110,69 & 100,83 & 154,70 & 1327,55 & 1107,28 & 1647,09 & 1599,55 & \\
\hline & $\mathrm{N}$ & 28 & 23 & 45 & 42 & 37 & 48 & 44 & 37 & 154 & 150 & \\
\hline
\end{tabular}

Abbreviations: $\mathrm{PCl}$ - percutaneous coronary intervention, $\mathrm{RA}$ - energy expenditure of recreational activity, HA - energy expenditure of household activity, Total - energy expenditure of either RA, HA or both forms of activity, SD - standard deviation.

( $>6$ MET) there was a significant drop of the energy expenditure noted in all ranges (Table 4 ).

There was a significant increase of work tolerance noted during the stress test 6 months after the angioplasty. There were considerable changes in values of all observed parameters. Patients, whose physical activity in leisure time was in the range of 2000-2999 and over $3000 \mathrm{kcal} / \mathrm{week}$, obtained the most significant improvement during the stress test (Table 5).

The echocardiography examination performed 6 months after the angioplasty showed improvement of the heart structure dimensions. Statistically significant changes (within the normal range) considered the LVESD and LVEF\% values. In the group of patients whose weekly energy expenditure was below $2000 \mathrm{kcal} /$ week, there was a slight increase of the dimensions in majority of parameters, except for LVEF\%, where there was a small decrease (within the normal range) observed in the group of patients with weekly energy expenditure under $999 \mathrm{kcal} /$ week (Table 6).

There were weak correlations observed between total energy expenditure calculated with the MLTPAQ stress test parameters and ECHO results (Table 7 and Table 8).

\section{Discussion}

The average amount of weekly energy expenditure related to recreational activity, and therefore the one which is of great importance for prevention of cardiovascular 
Table 5

Selected parameters of stress test in relation to the intensity ranges of activity calculated with the MLTPAQ

\begin{tabular}{|c|c|c|c|c|c|c|c|c|c|c|c|c|}
\hline \multicolumn{2}{|l|}{ Parameter } & \multicolumn{2}{|c|}{ below 999 kcal } & \multicolumn{2}{|c|}{$1000-1999 \mathrm{kcal}$} & \multicolumn{2}{|c|}{$2000-2999 \mathrm{kcal}$} & \multicolumn{2}{|c|}{ over $3000 \mathrm{kcal}$} & \multicolumn{3}{|l|}{ TOTAL } \\
\hline & & $\begin{array}{l}\text { before } \\
\mathrm{PCl}\end{array}$ & $\begin{array}{l}6 \text { months } \\
\text { after } \mathrm{PCl}\end{array}$ & $\begin{array}{l}\text { before } \\
\mathrm{PCl}\end{array}$ & $\begin{array}{l}6 \text { months } \\
\text { after } \mathrm{PCl}\end{array}$ & $\begin{array}{l}\text { before } \\
\mathrm{PCl}\end{array}$ & $\begin{array}{l}6 \text { months } \\
\text { after } \mathrm{PCl}\end{array}$ & $\begin{array}{l}\text { before } \\
\mathrm{PCl}\end{array}$ & $\begin{array}{l}6 \text { months } \\
\text { after } \mathrm{PCl}\end{array}$ & $\begin{array}{l}\text { before } \\
\mathrm{PCl}\end{array}$ & $\begin{array}{l}6 \text { months } \\
\text { after } \mathrm{PCl}\end{array}$ & $\mathrm{P}$ \\
\hline \multirow{3}{*}{$\begin{array}{l}\text { Test duration } \\
\text { [min] }\end{array}$} & Mean & 5,70 & 5,64 & 5,71 & 7,16 & 5,31 & 7,35 & 6,15 & 8,18 & 4,24 & 6,32 & $<0,001$ \\
\hline & SD & 2,79 & 2,40 & 2,44 & 2,06 & 2,57 & 2,70 & 2,86 & 2,39 & 2,22 & 3,12 & \\
\hline & $\mathrm{N}$ & 33 & 18 & 57 & 45 & 37 & 42 & 82 & 73 & 154 & 150 & \\
\hline \multirow{3}{*}{$\begin{array}{l}\text { Metabolic cost } \\
\text { [MET's] }\end{array}$} & Mean & 7,51 & 7,70 & 7,68 & 8,95 & 7,01 & 9,26 & 7,73 & 9,66 & 6,52 & 8,21 & $<0,001$ \\
\hline & SD & 2,76 & 2,70 & 2,71 & 2,38 & 2,54 & 3,02 & 2,66 & 2,38 & 1,26 & 2,86 & \\
\hline & $\mathrm{N}$ & 33 & 18 & 57 & 45 & 37 & 42 & 82 & 73 & 154 & 150 & \\
\hline \multirow{3}{*}{$\begin{array}{l}\text { VO2max } \\
{[\mathrm{ml} / \mathrm{kg} / \mathrm{min}]}\end{array}$} & Mean & 28,93 & 27,16 & 28,54 & 32,90 & 27,70 & 34,54 & 30,49 & 37,94 & 28,23 & 32,52 & $<0,001$ \\
\hline & SD & 9,55 & 7,16 & 8,32 & 8,65 & 9,32 & 10,95 & 11,50 & 11,02 & 5,94 & 8,25 & \\
\hline & $\mathrm{N}$ & 33 & 18 & 57 & 45 & 37 & 42 & 82 & 73 & 154 & 150 & \\
\hline \multirow{2}{*}{$\begin{array}{l}\text { HR resting } \\
\text { [beats/min] }\end{array}$} & Mean & 75,55 & 75,94 & 77,44 & 71,82 & 78,70 & 73,79 & 77,10 & 73,52 & 72,00 & 70,00 & $<0,001$ \\
\hline & $\mathrm{N}$ & 33 & 18 & 57 & 45 & 37 & 42 & 82 & 73 & 154 & 150 & \\
\hline \multirow{3}{*}{$\begin{array}{l}\text { HR max } \\
\text { [beats/min] }\end{array}$} & Mean & 120,52 & 136,50 & 120,38 & 132,04 & 125,65 & 129,50 & 125,90 & 131,78 & 118,00 & 129,00 & $<0,001$ \\
\hline & SD & 15,56 & 11,64 & 18,89 & 15,02 & 18,23 & 15,51 & 16,09 & 14,85 & 14,52 & 16,47 & \\
\hline & $\mathrm{N}$ & 33 & 18 & 57 & 45 & 37 & 42 & 82 & 73 & 154 & 150 & \\
\hline \multirow{2}{*}{$\begin{array}{l}\text { HR submax not } \\
\text { reached }\end{array}$} & $\mathrm{N} / \Sigma$ & $16 / 17$ & $6 / 20$ & $43 / 51$ & $16 / 46$ & $24 / 33$ & $11 / 41$ & $35 / 53$ & $15 / 43$ & $118 / 154$ & $48 / 150$ & $<0,001$ \\
\hline & $\%$ & $94,11 \%$ & $30,00 \%$ & $84,31 \%$ & $34,78 \%$ & $72,72 \%$ & $26,82 \%$ & $66,03 \%$ & $34,88 \%$ & $76,62 \%$ & $32,00 \%$ & \\
\hline \multirow{2}{*}{$\begin{array}{l}\text { Positive results } \\
\text { of stress test }\end{array}$} & $\mathrm{N} / \Sigma$ & $21 / 30$ & $8 / 23$ & $33 / 41$ & $11 / 30$ & $26 / 32$ & $16 / 37$ & $41 / 51$ & $7 / 60$ & $121 / 154$ & $42 / 150$ & $<0,001$ \\
\hline & $\%$ & $70,00 \%$ & $34,78 \%$ & $80,48 \%$ & $36,66 \%$ & $81,25 \%$ & $43,24 \%$ & $80,39 \%$ & $11,66 \%$ & $78,57 \%$ & $28,00 \%$ & \\
\hline
\end{tabular}

Abbreviations: $\mathrm{PCl}$ - percutaneous coronary intervention, $\mathrm{MET}$ - metabolic cost, $\mathrm{VO}_{2}$ max - maximal oxygen consumption, $\mathrm{HR}_{\text {rest }}$ - resting heart rate, $\mathrm{HR}$ max - maximal heart rate: HR sumbax - HR calculated with formula: $(220$ - age) $\times 0,85$; SD - standard deviation.

Table 6

Selected echocardiography variables, in relation to the intensity ranges of activity calculated with the MLTPAQ

\begin{tabular}{|c|c|c|c|c|c|c|c|c|c|c|c|c|}
\hline \multicolumn{2}{|c|}{ Parameter } & \multicolumn{2}{|c|}{ below 999 kcal } & \multicolumn{2}{|c|}{$1000-1999$ kcal } & \multicolumn{2}{|c|}{ 2000-2999 kcal } & \multicolumn{2}{|c|}{ over 3000 kcal } & \multicolumn{3}{|l|}{ TOTAL } \\
\hline & & $\begin{array}{l}\text { before } \\
\mathrm{PCl}\end{array}$ & $\begin{array}{l}6 \text { months } \\
\text { after PCl }\end{array}$ & $\begin{array}{l}\text { before } \\
\mathrm{PCl}\end{array}$ & $\begin{array}{l}6 \text { months } \\
\text { after } \mathrm{PCl}\end{array}$ & $\begin{array}{l}\text { before } \\
\mathrm{PCl}\end{array}$ & $\begin{array}{l}6 \text { months } \\
\text { after } \mathrm{PCl}\end{array}$ & $\begin{array}{l}\text { before } \\
\mathrm{PCl}\end{array}$ & $\begin{array}{l}6 \text { months } \\
\text { after } \mathrm{PCl}\end{array}$ & $\begin{array}{l}\text { before } \\
\mathrm{PCl}\end{array}$ & $\begin{array}{l}6 \text { months } \\
\text { after } \mathrm{PCl}\end{array}$ & $P<$ \\
\hline \multirow{3}{*}{$\begin{array}{l}\text { LVEF\% } \\
{[\%]}\end{array}$} & Mean & 51,33 & 50,56 & 53,37 & 53,45 & 49,76 & 52,62 & 51,12 & 52,42 & 50,45 & 51,36 & $<0,02$ \\
\hline & SD & 9,12 & 9,85 & 8,03 & 8,00 & 7,64 & 7,21 & 10,26 & 8,69 & 7,21 & 6,12 & \\
\hline & $\mathrm{N}$ & 33 & 27 & 57 & 47 & 37 & 47 & 82 & 81 & 154 & 150 & \\
\hline
\end{tabular}

Abbreviations: $\mathrm{PCl}$ — percutaneous coronary intervention, LVEF\% — left ventricular ejection fraction, SD — standard deviation.

diseases $[12,14,15]$, did not exceed in our study the value of $2000 \mathrm{kcal} /$ week before the first PCI and was mainly of low intensity $-<4$ MET (morning warm-up exercises, walking, fishing), or of moderate intensity, 4-6 MET (cycling, including stationary cycling, general conditioning exercises). The range of physical activity remained below the level of $1000 \mathrm{kcal} /$ week.

Such low level of physical activity may result from limitation of exercise tolerance due to atherosclerotic process in coronary vessels or history of MI, but most likely from the sedentary lifestyle $[13,15,16]$. The majority of patients did not engage in any form of sport or recreational physical activity and even if they did, such activity was short-lasting and sporadic. There were however a few patients (6) who systematically participated in various forms of recreation (skiing, jogging, swimming); their weekly energy expenditure resulting from such activities very often exceeded the level of 2000 and sometimes even $3000 \mathrm{kcal}$ per week.

That group of few patients included individuals who used to do sports in the past or who were really enjoying such activities. After the angioplasty procedure the increase of the level of physical activity as well as energy expenditure was anticipated. We assumed that one factor which would favourably affect patients' attitude to physical activity was the cardiac rehabilitation programme, both in hospital and in the health resort.

There was, however, no increase in total weekly energy expenditure noted after the PCI procedure; nor was there in the intensity or type of performed activities. During the 6-month period preceding the second PCI, patients engaged mainly in recreational activities of low intensity, in the range of 1000-1999 or 2000-2999 kcal/week, and in household activities of moderate intensity (4-6 MET). 
The values of these activities however still remained at an unchanged level. We found an improvement in variables obtained at the second ET. The higher the increase in energy expenditure in relation to the initial examination, the more the improvement in selected ET parameters was noted. Patients who exceeded the value of $2000 \mathrm{kcal} /$ week after the first PCI were able to exercise longer, resulting in higher values of obtained MET, VO2max and maximal HR. In this group of patients, there was a considerable increase in the number of patients reaching the level of submaximal HR and a decrease in the number of positive ET results. Similar findings were reported by Nowak et al [13]. The angioplasty procedure restores proper circulation in coronary arteries, improves work tolerance and thus allows patient to exercise longer and with increased intensity. The procedure resulted in improvement of left ventricle function of studied subjects (increase in EF\%) what was also reported by other authors [17-20]. We also evaluated correlation between the delta of energy expenditure assessed in the questionnaire versus the delta of selected parameters of treadmill stress test and echocardiography examination. As far as stress test results were concerned we found weak correlation with the delta of test time and $\mathrm{VO} 2$ max. There was however no association with the delta values of echocardiography procedure. This situation may result from patients' fear of ischemic symptoms reproduction associated with considerable chest pain and perhaps from their unwillingness to physical effort in general.

\section{Conclusion}

Our findings suggest that MLTPAQ may be used as an additional tool in clinical assessment of patients undergoing PCI. The results obtained in this study indicate that the level of leisure time physical activity in studied subjects was

\section{References}

1. Sirard JR, Hannan PC, Gretchen J, et al. Evaluation of 2 Self-Report Measures of Physical Activity With Accelerometry in Young Adults. J Phys Health Act 2013; 10 (1): 85-96.

2. Rothney MP, Schaefer EV, Neumann MM, et al. Validity of physical activity intensity predictions by ActiGraph, Actical, and RT3 accelerometers. Obesity (Silver Spring) 2008;16 (8): 1946-52.

3. Zakeri I, Adolph AL, Puyau MR, et al. Application of cross-sectional time series modeling for the prediction of energy expenditure from heart rate and accelerometry. $\mathrm{J} \mathrm{Appl}$ Physiol 2008;104 (6):1665-69.

4. Koebnick C, Wagner K, Thielecke F, et al. Validation of a simplified physical activity record by double labeled water technique. Int J Obes (Lond) 2005;29 (3): 302-9.

5. Westerterp KR. Physical activity and physical activity induced energy expenditure in humans: measurement, determinants, and effects. Front Physiol 2013;26;4: 90.

6. Ainsworth BE, Caspersen CJ, Matthews CE, et al. Recommendations to improve the accuracy of estimates of physical activity derived from self-report. Journal of Physical Activity \& Health 2012; Supplement, 9, S76.

7. Rubenstein JH, Morgenstern H, Kellenberg J, et al. Validation of a New Physical Activity Questionnaire for a Sedentary Population. Dig Dis Sci 2011;56 (9): 2678-87.

8. Florindo AA, Romero A, Peres SV, et al. Development and validation of a physical activity assessment questionnaire for adolescents. Rev Sa de P blica 2006;40 (5):1-7.

9. Jorstad-Stein EC, Hauer K, Becker C., et al. Suitability of Physical Activity Questionnaires for Older Adults in Fall-Prevention Trials: A Systematic Review Journal of Aging and Physical Activity 2005;13: 461-81.

10. Dugdill L, Crone D, Murphy R. Physical Activity and Health Promotion: Evidence-based Approaches to Practice. John Wiley \& Sons 2009: 263
Table 7

Correlation indices between total energy expenditure calculated with MLTPAQ, stress test parameters and ECHO results

\begin{tabular}{|c|c|c|c|}
\hline & Exercise stress test & r & $P$ \\
\hline $\operatorname{MLTPAQ}^{*} \Delta^{\dagger}$ & Time $\Delta^{\dagger}$ & 0,198 & $<0,002$ \\
\hline MLTPAQ $\Delta$ & MET $\Delta$ & 0,158 & $<0,057$ \\
\hline MLTPAQ $\Delta$ & $\mathrm{VO}_{2} \max \Delta$ & 0,255 & $<0,001$ \\
\hline MLTPAQ $\Delta$ & Rest.HR $\Delta$ & 0,159 & $<0,048$ \\
\hline MLTPAQ $\Delta$ & $\mathrm{HR} \max \Delta$ & 0,134 & $<0,087$ \\
\hline
\end{tabular}

"Minnesota Leisure Time Physical Activity Questionnaire; ${ }^{\dagger} \Delta$ : the result of subtraction of the first and second examination and MLTPAQ values.

Table 8

Correlation indices between total energy expenditure calculated with MLTPAQ, and ECHO results (EF\%)

\begin{tabular}{|l|l|l|l|} 
& Echocardiography & $r$ & $P$ \\
\hline MLTPAQ $^{\star} \Delta^{\dagger}$ & EF\% $\Delta$ & 0,028 & $<0,624$
\end{tabular}

"Minnesota Leisure Time Physical Activity Questionnaire; ${ }^{\dagger} \Delta$ : the result of subtraction of the first and second examination and MLTPAQ values.

below the value recommended for primary and secondary prevention of IHD. We assume that improvement of patients' clinical status 6 months after the PCI resulted from high effectiveness of that procedure and participation in two phases of cardiac rehabilitation.

\section{Clinical Rehabilitation Impact}

The helpfulness of the research may be used in the work of cardiologists or physiotherapists. The research will allow to estimate the actual level of physical activity and physical endurance of patients that were treated by angioplasty. Moreover, this is the simple and cheap method of estimation.

11. Haskell WL, Lee IM, Pate RR, et al. A Physical Activity and Public Health: Updated Recommendation for Adults From the American College of Sports Medicine and the American Heart Association Med Sci Sports Exerc 2007;39 (8): 1423-34.

12. Ainsworth BE, Haskell WL, Herrmann SD, et al. Compendium of Physical Activities: second update of codes and MET values. Med Sci Sports Exerc 2011; 43 (8): 1575-81.

13. Nowak Z, Plewa M, Skowron M, et al. Paffenbarger Physical Activity Questionnaire as an additional tool in clinical assessment of patients with coronary artery disease treated with angioplasty. Kardiol Pol 2010; 68 (1): 32-9.

14. Nelson ME, Rejeski WJ, Blair SN, et al. Physical Activity and Public Health in Older Adults. Recommendation From the American College of Sports Medicine and the American Heart Association. Circ 2007;116: 1094-105.

15. Steffen LM, Arnett DK, Blackburn H, et al. Population Trends in Leisure-Time Physical Activity: Minnesota Heart Survey, 1980-2000. Med Sci Sports Exerc 2006;38 (10): 1716-23.

16. Brändström $Y$, Brink E, Grankvist $\mathrm{G}$, et al. Physical activity six months after a myocardia infarction. Int J Nurs Pract.2009; 15 (3): 191-7.

17. Agirbasli $\mathrm{M}$, Guler N. Recovery of left ventricular systolic function after left anterior descending coronary artery stenting. J Interv Cardiol.2005;18 (2):83-8.

18. Hu FB, Tamai H, Kosuga $\mathrm{K}$, et al. Predictors of improvement in left ventricular function after initially successful angioplasty of unprotected left main coronary artery stenoses. Int J Cardiovasc Intervent 2004; 6 (3-4): 119-27.

19. Zellweger MJ, Tabacek G, Zutter AW, et al. Evidence for left ventricular remodeling after percutaneous coronary intervention: effect of percutaneous coronary intervention on left ventricular ejection fraction and volumes. Int J Cardiol 2004;96 (2):197-201.

20. Nechvatal L, Hlinomaz O, Groch L, et al. Serial echocardiographic assessment of left ventricular function after direct PCI. Kardiol Pol 2003; 59 (11):397-401. 